Сочиолошки преглед, vol. XLIII (2009), no. 3, стр. 329-341

Valentina Sokolovska

UDK: 314.54

Faculty of Philosophy, Novi Sad

Katarina Čobanović

Оригиналан научни рад

Slobodan Nićin

Faculty of Agriculture, Novi Sad

Примљен: 25. 9. 2009.

\title{
STATISTICAL ANALYSIS OF MARITAL STATUS OF THE VOJVODINA POPULATION ${ }^{1}$
}

The marital status of the population of Vojvodina was analyzed in this paper using statistical methods. The analysis is based on the Census results for 1991 and 2002. The period between the two last Censuses (1991-2002) is characterized by very dynamic social changes in Serbia (Central Serbia and Vojvodina). These changes had very important influences on changes of the population marital status. The analysis is focused on the basic indicators of marital structure: the average age of population when forming or dissolving unions, the coefficient of divorciality by sex and by age groups, etc. The attention in the analysis is placed on research of similarities and differences in marital status of population of Vojvodina according to the settlement types: urban or rural.

Key words: marital status, Vojvodina, statistical analysis.

\section{Introduction}

On the basis of previous research it is possible to outline some of the most general characteristics of marital status on the territory of Vojvodina: the decrease of universality of marriage, marriages at older ages, the increase of the types of relationships other than traditional marriage (for example, co-habitations without formal marriage, single-parent families) as well the decrease of fertility (Bobić, 2006, Rašević, 2006, Petrović, 2006).

Such marital structures are a result of constant social turmoil which took place on the territory of the Republic of Serbia between the two last Censuses (19912002). Apart from social-political factors (the breakup of the former country of Yugoslavia, civil wars in the immediate vicinity, bombing of the Republic of Serbia, and so on), economic factors (imposing sanctions on the country, weakening of the country's overall economy which resulted in population's impoverishment, increasing unemployment and so on) we can also underline a number of cultural factors which influenced the changes of marital structure.

${ }^{1}$ The paper is a part of the project financially supported by the Ministry of Science of the Republic of Serbia (Projects No. 149013D and No. 149007). 
V. Sokolovska, K. Čobanović, S. Nićin, Statistical Analysis of Marital Status...

According to the results of the Census of Population, Households and Dwellings of 2002, it is possible to determine the characteristics and the pace of marital status changes of the population of Serbia and Vojvodina during the last decade of $20^{\text {th }}$ century. This paper focuses on the characteristics of marital status of the population of Vojvodina. The changes of demographic, as well as of marital status structure in Vojvodina are similar to the changes observed at the level of the Republic of Serbia. According to certain authors, in the after-war period - after the World War II, the marital status changes of the population of Serbia had a course similar to the changes in marital status in developed European countries (Petrović, 2006). According to the same author, the characteristics of marital status of the population of Serbia (Central Serbia and Vojvodina) in 2002 were similar to the characteristics of marital status of developed European countries in mid-80s. Slower changes in marital status of the population of Serbia are a consequence of social-economic development, and not of demographic one. Accordingly, the authors of this paper tried to explain marital status changes of the population of Vojvodina as a consequence of influences of social-economic, cultural and other factors. Development of agriculture and rural development in the last century were also very intensive and had great influences on the population changes. Due to these reasons, the paper examines the population's marital structure in respect to the types of settlements: urban and rural.

The marital status of Vojvodinian population between the two last Censuses (1991-2002) is characterized by the model of marital status typical for developed European countries (Petrović, 2006). Namely, in the period between 1991 and 2002 there was a tendency of decreasing inhabitants' participation in marriages, and increasing participation of inhabitants who had never been married. In the same time, there was growing participation of divorced population in the marital structure. Thus, it was determined that, at the level of Vojvodina, there was an increase of single population in $2002(25.4 \%)$, compared to $1991(20.0 \%)$. The participation of the married in $2002(58.6 \%)$ was lower compared to $1991(66.3 \%)$. The participation of divorced population in 2002 (4.4\%) increased in comparison to 1991 (3.9\%).

This paper also examines the population's marital structure in respect to the types of their settlements. The analysis of marital status in relation to the types of settlements bears great significance knowing that cities are the bearers of modernization and individualization of life and working styles, etc. It is the type of a settlement that is supposed to have great influence on the changes of marital status, which is primarily reflected in the increased participation of single and divorced population. On the basis of published statistical data for 2005 rural ("other") settlements (415) prevail compared to urban settlements (52).

T-test is used for examining the differences in respect to the settlement types in 2002, as well as the differences between the two groups of families: the families with and without children. "Box-plot" diagrams were used for the purposes of illustrating statistical significances between families with children and without 
Социолошки преглед, vol. XLIII (2009), no. 3, стр. 329-341

children (STATISTICA 8.0). This kind of plot was very suitable in the analysis because the variables are discrete.

The influence of certain characteristics of marital status is examined by applying the regression analysis. Also, application the procedure of forward stepwise regression was used for analyzing the models of multiple linear regretssion, with the relevant regressors having significant influence on the dependent variable. The classical regression approach often encounters acute computational difficulty, especially when many variables are involved and when there is not enough information about the form of an appropriate functional linear model to fit the data. This can be overcome by using the technique of stepwise multiple regression (Čobanović, Nikolić-Đorić, 1995). The basic idea of this technique is that it allows one to overestimate the complexity of the potential linear model which is to be statistically analyzed. From this model a 'statistically significant' sub-model is determined by following certain criteria of fit and tests of significance with main aim of elimination of insignificant terms (Breaux, Campbell, Torrey, 1966). Variables that have been analyzed in this study were following: Total Number of Population, Number of Population (Urban Settlements), Number of Population ("Other" Settlements), Total Number of Families, Number of Families with Children, Number of Families without Children, Total Number of Families (Urban Settlements), Number of Families with Children (Urban Settlements), Number of Families without Children (Urban Settlements), Total Number of Families ("Other" Settlements), Number of Families with Children ("Other" Settlements), Number of Families without Children ("Other" Settlements), Total Number of Settlements, Number of Urban Settlements and Number of "Other" Settlements.

The statistical analysis is conducted by applying STATISTICA 8.0 statistic software.

\section{Results}

A detailed analysis of the Vojvodinian population marital status was carried out on the basis of the 2002 Census results.

The examination of the analyzed elements of marital status of the Vojvodinian population is based on the municipalities and counties data. In 2002, there were 45 municipalities and 7 counties registered.

In 2005 there were 467 settlements in total in Vojvodina, out of which 52 are urban settlements, and 415 are other types of settlements (rural settlements). The average total number of settlements per a municipality in Vojvodina is 10.38 (with standard deviation of 6.19), the average number of urban settlements per a municipality is 1.16 (with standard deviation of 0.71 ), while the average number of other settlements is 9.22 (with standard deviation of 6.13).

The distribution of urban settlements in municipalities is as follows: there are 37 municipalities with 0 to 1 urban settlements, 7 municipalities with 2 to 3 
V. Sokolovska, K. Čobanović, S. Nićin, Statistical Analysis of Marital Status...

urban settlements, and only one municipality with 4 urban settlements (the municipality of Novi Sad). The distribution of municipalities according to the number of other settlements is as follows: there are 3 municipalities with $0-2$ other settlements, 12 municipalities with 3-5 other settlements, 10 municipalities with 68 other settlements, 6 municipalities with 9-11 other settlements, 5 municipalities with 12-14 other settlements, 4 municipalities with 15-18 other settlements, and 5 municipalities with 18 or more other settlements.

Graph 1. Distribution of Urban Settlements by Counties

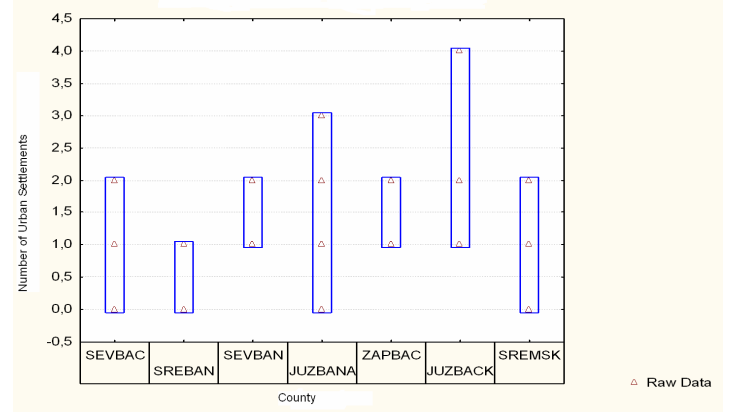

Graph 2. Distribution of Other Settlements by Counties

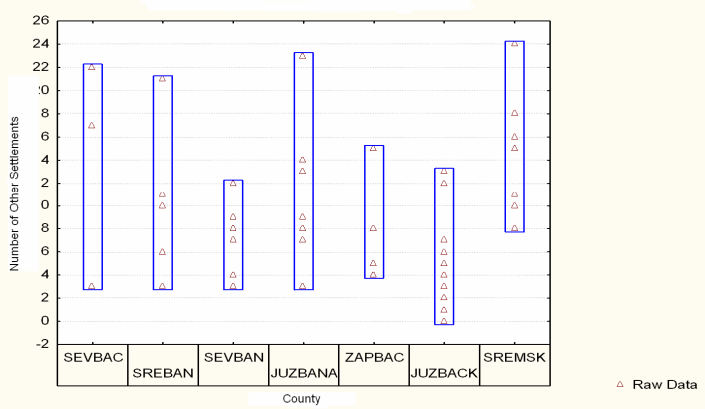

The distribution of urban settlements in counties is as follows: there are 2 counties with 0-2 settlements, 1 county with $0-1$ settlements, 2 counties with 1-2 settlements, 1 county with 0-3 settlements and 1 county 1-4 settlements (Graph 1 ). 
Сочиолошки преглед, vol. XLIII (2009), no. 3, стр. 329-341

The distribution of "other" settlements in counties is as follows: NorthernBacka county has 3-22 settlements, Middle-Banat county has 3-21, Northern-Banat county has 3-12, South-Banat county has 3-23, Western-Backa county has 4-15, South-Backa county has 0-13 and Srem county has 8-24 settlements (Graph 2).

During the period between the two Censuses, there were changes regarding the family structure in Vojvodina in respect to the type of the settlement, as well as to the type of families: families with or without children. In 1991, the participation of a "married couple with children" family type in the total number of families was $57.6(\%)$, while in 2002 its participation was a little lower counting $55.6(\%)$. The participation of a "married couple without children" family type in the total number of families in 1991 was $31.9(\%)$, to be lowered in 2002 to $29.3(\%)$. In urban settlements the participation of a "married couple with children" family type in 1991 was high (58.9\%), to be slightly lowered in 2002 (56.0\%). The participation of a "married couple without children" family type in urban settlements (29.2\%) in 1991 was higher compared to 2002 (27.5\%). Regarding other settlements, the participation of "married couple with children" families was on both Censuses approximately the same (55.0\% in 1991 and $55.1 \%$ in 2002). The situation was similar for the participation of "married couple without children" families for other settlements (32.3\% in 1991 and $31.5 \%$ in 2002).

During the examined period, the following categories increased: the single population (1991: 20.0\%, 2002: 25.4\%), widowers/widows (1991: 9.8\%, 2002: $11.5 \%$ ), and divorced population (1991: 3.9\%, 2002: 4.4\%), while the category of the married population decreased (1991: 66.3\%, 2002: 58.7\%) (Bobić, 2006). Another indicator that more and more inhabitants decide not to get married at all is the fact that the number of celibacies increased in all age groups, both for the males and females (Bobić, 2006). As a consequence of longer life expectancy, but also due to postponing of marriages with younger generations, the average age is increased for all the categories of marital status. Thus, husbands' average age when entering into their first marriage in Vojvodina was the age of 27.2 in 1991, to be raised in 2002 to the age of 28.6. There is a similar situation with the average age of females when entering into the first marriage: the age of 23.7 (in 1991), and 25.3 (in 2002) (Bobić, 2006). According to the same author, the average age of entering into the first marriage in certain developed European countries around the year 2000 , for female population, was relatively high ranging from the age of 27.2 to the age of 30.1 .

The rate of nuptiality, divorciality and divorce rate are also significant indicators of the nature of population's marital structure. During the analyzed period (1991-2002), the total number of marriages in Vojvodina decreased, according to the annual rate of changes amounted $-0.220(\%)$ on the yearly basis. In the same time span, the total number of divorces decreased by the annual rate of change of $-0.093(\%)$. The divorce rate, calculated as a ratio of the number of divorces and the number of marriages, in the relevant period was increased by the average annual growth rate of $0.125(\%)$ on the yearly basis. The divorce rate could 
V. Sokolovska, K. Čobanović, S. Nićin, Statistical Analysis of Marital Status...

be considered as an indicator of the marital structure deviations of the Vojvodinian population, which was taking place during the last decade of $20^{\text {th }}$ century.

The average number of children per a family in Vojvodina in 1991 was 2.2, while in 2002 it was 2.0.

Table 1. Descriptive Statistics for Analyzed Variables

\begin{tabular}{|c|c|c|c|c|c|}
\hline \multicolumn{6}{|c|}{ Descriptive Statistics } \\
\hline & Valid N & Mean & Minimum & Maximum & Std.Dev. \\
\hline Total Number of Population & 45 & 45155.38 & 8839.000 & 299294.0 & 50986.15 \\
\hline Number of Population (Urban Settlements) & 45 & 25606.56 & 0.000 & 235165.0 & 39546.11 \\
\hline $\begin{array}{c}\text { Number of Population (“Other" } \\
\text { Settlements) }\end{array}$ & 45 & 19548.82 & 0.000 & 64129.0 & 14324.30 \\
\hline Total Number of Families & 45 & 13227.24 & 2589.000 & 87332.0 & 14919.96 \\
\hline Number of Families with Children & 45 & 7350.27 & 1482.000 & 49563.0 & 8418.29 \\
\hline Number of Families without Children & 45 & 3873.16 & 694.000 & 22127.0 & 3957.22 \\
\hline $\begin{array}{c}\text { Total Number of Families (Urban } \\
\text { Settlements) }\end{array}$ & 45 & 7510.38 & 0.000 & 68688.0 & 11559.21 \\
\hline $\begin{array}{c}\text { Number of Families with Children (Urban } \\
\text { Settlements) }\end{array}$ & 45 & 4202.62 & 0.000 & 38081.0 & 6405.92 \\
\hline $\begin{array}{l}\text { Number of Families without Children } \\
\text { (Urban Settlements) }\end{array}$ & 45 & 2069.76 & 0.000 & 17386.0 & 3010.70 \\
\hline $\begin{array}{c}\text { Total Number of Families (“Other” } \\
\text { Settlements) }\end{array}$ & 45 & 5716.87 & 0.000 & 18644.0 & 4207.79 \\
\hline $\begin{array}{l}\text { Number of Families with Children } \\
\text { ("Other" Settlements) }\end{array}$ & 45 & 3147.644 & 0.00 & 11482.00 & 2444.659 \\
\hline $\begin{array}{l}\text { Number of Families without Children } \\
\text { ("Other" Settlements) }\end{array}$ & 45 & 1803.400 & 0.00 & 4900.00 & 1232.167 \\
\hline Total Number of Settlements & 45 & 10.37778 & 1.000000 & 26.00000 & 6.191229 \\
\hline Number of Urban Settlements & 45 & 1.15556 & 0.000000 & 4.00000 & 0.705677 \\
\hline Number of "Other" Settlements & 45 & 9.22222 & 0.000000 & 24.00000 & 6.130731 \\
\hline
\end{tabular}

\section{Variables:}

$X_{1}$ - Total Number of Population

$X_{2}$ - Number of Population (Urban Settlements)

$X_{3}$ - Number of Population ("Other" Settlements)

$X_{4}$ - Total Number of Families

$X_{5}$ - Number of Families with Children

$X_{6}$ - Number of Families without Children

$X_{7}^{6}$ - Total Number of Families (Urban Settlements)

$X_{8}$ - Number of Families with Children (Urban Settlements)

$X_{9}$ - Number of Families without Children (Urban Settlements)

$X_{10}$ - Total Number of Families ("Other" Settlements) 
$X_{11}$ - Number of Families with Children ("Other" Settlements)

$X_{12}$ - Number of Families without Children ("Other" Settlements)

$X_{13}$ - Total Number of Settlements

$X_{14}$ - Number of Urban Settlements

$X_{15}$ - Number of "Other" Settlements

According to the t-test, it was possible to ascertain significant changes between the families with respect to the families with or without children. The number of families (with or without children) is presented per capita. At the level of urban settlements, a significant difference was observed between the number of families with children and without children (per capita), while the value of the $t$-test $(t=9.166 ; p \leq 0.000000)$ is statistically relevant (Graph 3$)$.

Graph 3. Box and Whisker Plot of

Families of Urban Settlements with Children (First Group) and without Children

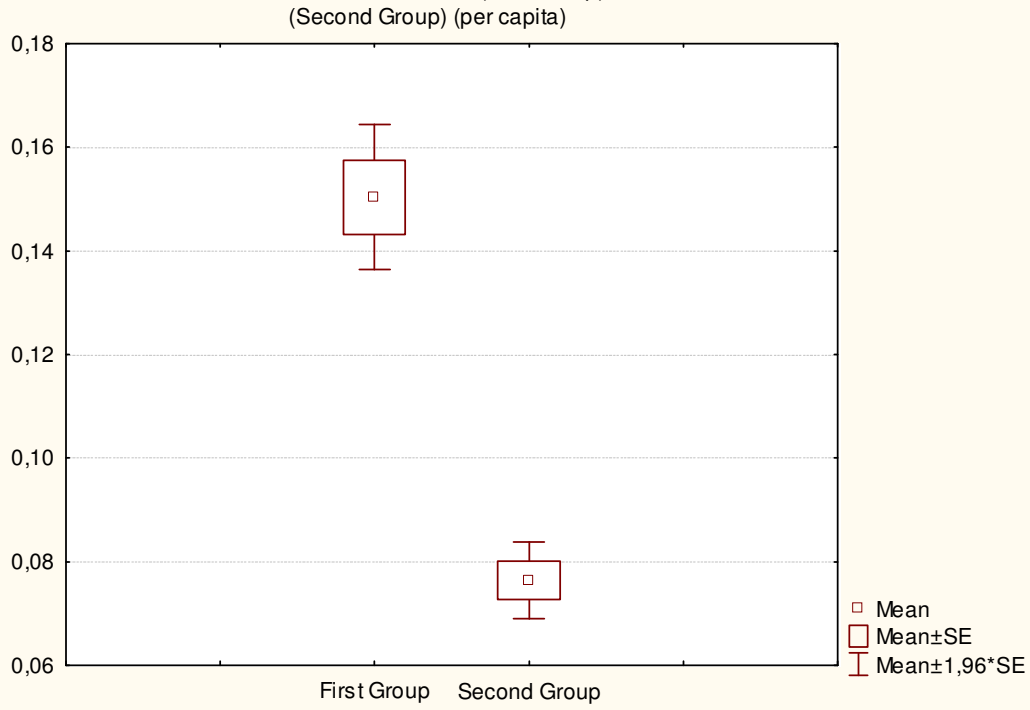


V. Sokolovska, K. Čobanović, S. Nićin, Statistical Analysis of Marital Status...

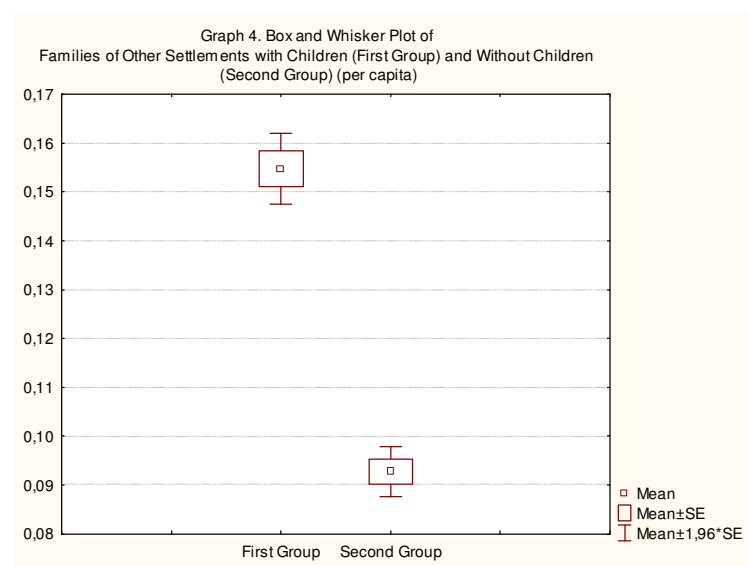

Regarding other settlements, $t$-test is also statistically relevant $(t=13.654 ; p=0.000000)$ indicating that the families with children outnumber the families without children (Graph 4).

When the numbers of families with children in urban and other settlements were compared, there was no statistical relevance $(t=-0.541 ; p=0.589496)$ (Graph 5).

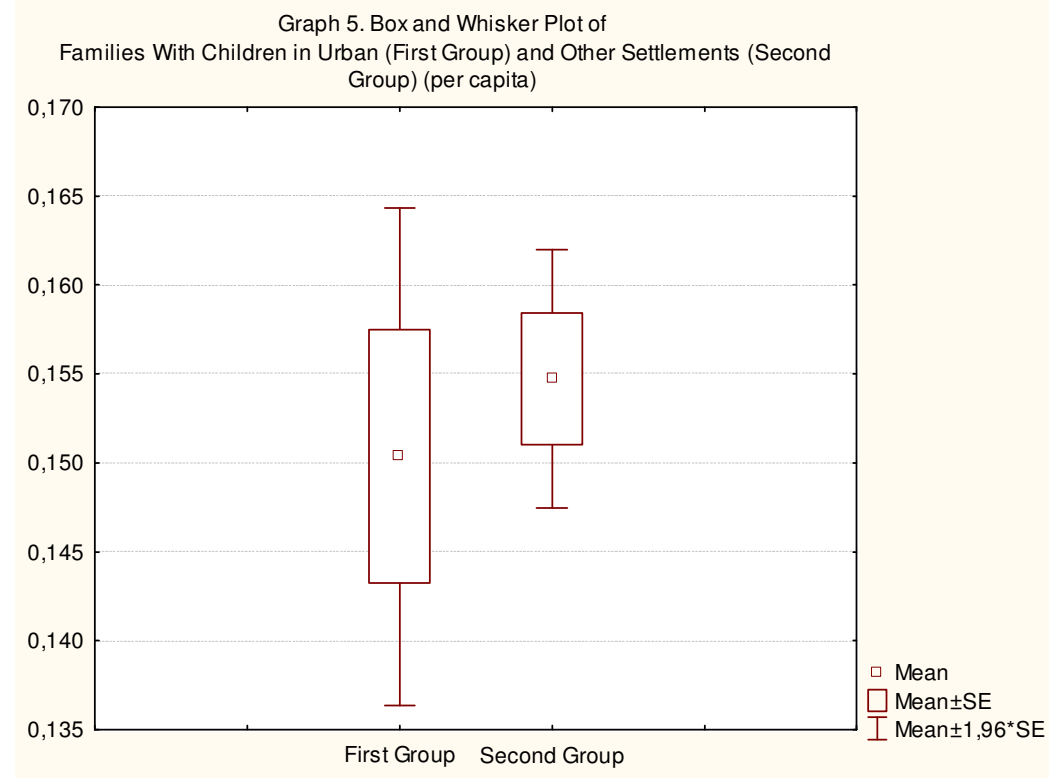




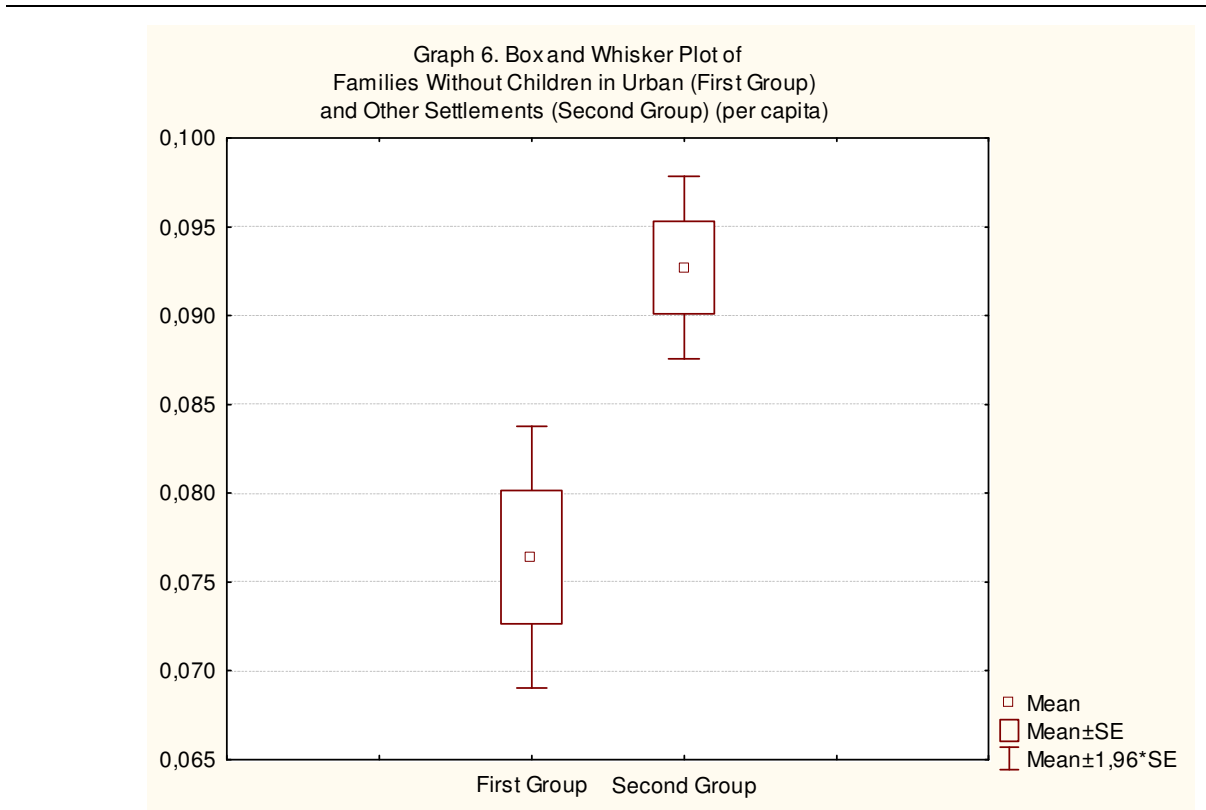

However, comparing the families without children in urban and other settlements shows statistical relevance denoting that the families without children in other settlements prevail in relation to the urban settlements $(t=-3.557$; $p=0.000607$ ) (Graph 6).

The results of regression analysis show that the number of families with children in urban settlements is significantly influenced by the total number of families in urban settlements $\left(X_{7}\right)$, the number of families without children in urban settlements $\left(X_{9}\right)$, as well as the number of population in urban settlements $\left(X_{2}\right)$, as illustrated by the following regression model (Table 2 ).

Table 2. Relation of Number of Families with Children and Other Variables (Urban Settlements)

Regression Summary for Dependent Variable: $X_{8} \quad R=0.99988600 \quad R^{2}=0.99977202$

Adjusted $R^{2}=0.99974922 F(4.40)=43854, p<0.0000$ Std. Error of estimate: 101.44

\begin{tabular}{|c|c|c|c|c|c|c|}
\hline & Beta & Std.Err. - of Beta & B & Std.Err. - of B & $t(40)$ & p-level \\
\hline Intercept & & & 52,09783 & 27,59655 & 1,88784 & 0.066317 \\
\hline$X_{7}$ & $\mathbf{2 . 0 2 6 3 3 4}$ & $\mathbf{0 . 2 2 3 7 8 3}$ & $\mathbf{1 . 1 2 2 9 6}$ & $\mathbf{0 . 1 2 4 0 2}$ & $\mathbf{9 . 0 5 4 8 9}$ & $\mathbf{0 . 0 0 0 0 0 0}$ \\
\hline
\end{tabular}


V. Sokolovska, K. Čobanović, S. Nićin, Statistical Analysis of Marital Status...

\begin{tabular}{|c|l|l|l|l|l|l|}
\hline$X_{9}$ & $\mathbf{- 0 . 1 7 7 8 7 1}$ & $\mathbf{0 . 0 3 4 3 7 4}$ & $\mathbf{- 0 . 3 7 8 4 6}$ & $\mathbf{0 . 0 7 3 1 4}$ & $\mathbf{- 5 . 1 7 4 5 9}$ & $\mathbf{0 . 0 0 0 0 0 7}$ \\
\hline$X_{2}$ & $\mathbf{- 0 . 8 6 3 8 7 7}$ & $\mathbf{0 . 2 2 4 2 5 0}$ & $\mathbf{- 0 . 1 3 9 9 4}$ & $\mathbf{0 . 0 3 6 3 3}$ & $\mathbf{- 3 . 8 5 2 2 9}$ & $\mathbf{0 . 0 0 0 4 1 4}$ \\
\hline$X_{5}$ & 0.014887 & 0.013264 & 0.01133 & 0.01009 & 1.12236 & 0.268401 \\
\hline
\end{tabular}

The number of families without children in urban settlements is determined by the total number of population $\left(X_{2}\right)$, the total number of families without children $\left(X_{6}\right)$ and the total number of families $\left(X_{4}\right)$, as illustrated by the following regression model (Table 3 ).

Table 3. Relation of Number of Families without Children and Other Variables (Urban Settlements)

Regression Summary for Dependent Variable: $X_{9} R=0.99962002, R^{2}=0.99924019$

Adjusted $R^{2}=0.99918459, F(3.41)=17973, p<0.0000$ Std. Error of estimate: 85.972

\begin{tabular}{|c|c|c|c|c|c|c|}
\hline & Beta & Std.Err. - of Beta & B & Std.Err. - of B & $t(41)$ & p-level \\
\hline Intercept & & & $-19,9750$ & 23.72792 & -0.8418 & 0.404764 \\
\hline$X_{2}$ & $\mathbf{1 . 0 7 7 1 6 4}$ & $\mathbf{0 . 0 2 3 7 6 2}$ & $\mathbf{0 . 0 8 2 0}$ & $\mathbf{0 . 0 0 1 8 1}$ & $\mathbf{4 5 . 3 3 1 8}$ & $\mathbf{0 . 0 0 0 0 0 0}$ \\
\hline$X_{6}$ & $\mathbf{0 . 6 6 0 2 3 7}$ & $\mathbf{0 . 0 4 4 9 7 1}$ & $\mathbf{0 . 5 0 2 3}$ & $\mathbf{0 . 0 3 4 2 1}$ & $\mathbf{1 4 . 6 8 1 3}$ & $\mathbf{0 . 0 0 0 0 0 0}$ \\
\hline$X_{4}$ & $\mathbf{- 0 . 7 3 2 7 1 4}$ & $\mathbf{0 . 0 5 7 8 8 4}$ & $\mathbf{- 0 . 1 4 7 9}$ & $\mathbf{0 . 0 1 1 6 8}$ & $\mathbf{- 1 2 . 6 5 8 3}$ & $\mathbf{0 . 0 0 0 0 0 0}$ \\
\hline
\end{tabular}

The number of families with children of other settlements is significantly determined by the influence of the number of families without children of other settlements $\left(X_{12}\right)$, the total number of families of other settlements $\left(X_{10}\right)$, as well as the total number of families with children $\left(X_{5}\right)$. This is presented by the following regression model (Table 4).

The number of families without children in other settlements is significantly influenced by the total number of families of other settlements $\left(X_{10}\right)$, the number of families with children in other settlements $\left(X_{11}\right)$, the number of inhabitants of other settlements $\left(X_{3}\right)$, as well as the total number of families without children $\left(X_{6}\right)$. The corresponding regression model is as follows (Table 5). 
Социолошки преглед, vol. XLIII (2009), no. 3, стр. 329-341

Table 4. Relation of Number of Families with Children and Other Variables ("Other" Settlements)

Regression Summary for Dependent Variable: $X_{11} R=0.99978849, R^{2}=0.99957703$

Adjusted $R^{2}=0.999534733, F(4.40)=23632, p<0.0000$ Std. Error of estimate: 52.732

\begin{tabular}{|c|c|c|c|c|c|c|}
\hline \multicolumn{1}{|c|}{} & Beta & Std.Err. - of Beta & B & Std.Err. - of B & $t(40)$ & p-level \\
\hline Intercept & & & 0,763493 & 16.02850 & 0.0476 & 0.962245 \\
\hline$X_{3}$ & -0.286119 & 0.187474 & -0.048831 & 0.03200 & -1.5262 & 0.134835 \\
\hline$X_{12}$ & $\mathbf{- 0 . 4 6 7 7 3 7}$ & $\mathbf{0 . 0 2 4 1 4 7}$ & $\mathbf{- 0 . 9 2 8 0 0 6}$ & $\mathbf{0 . 0 4 7 9 1}$ & $\mathbf{- 1 9 . 3 7 0 2}$ & $\mathbf{0 . 0 0 0 0 0 0}$ \\
\hline$X_{10}$ & $\mathbf{1 . 7 2 6 3 0 7}$ & $\mathbf{0 . 2 0 1 3 4 8}$ & $\mathbf{1 . 0 0 2 9 5 8}$ & $\mathbf{0 . 1 1 6 9 8}$ & $\mathbf{8 . 5 7 3 7}$ & $\mathbf{0 . 0 0 0 0 0 0}$ \\
\hline$X_{5}$ & $\mathbf{0 , 0 1 9 3 2 5}$ & $\mathbf{0 . 0 0 6 9 0 3}$ & $\mathbf{0 . 0 0 5 6 1 2}$ & $\mathbf{0 . 0 0 2 0 0}$ & $\mathbf{2 . 7 9 9 5}$ & $\mathbf{0 . 0 0 7 8 4 1}$ \\
\hline
\end{tabular}

Table 5. Relation of Number of Families without Children and Other Variables ("Other" Settlements)

Regression Summary for Dependent Variable: $X_{12} R=0.99914844 R^{2}=0.99829760$ Adjusted $R^{2}=0.99812736 F(4.40)=5864.1 p<0.0000$ Std. Error of estimate: 53.321

\begin{tabular}{|c|c|c|c|c|c|c|}
\hline \multicolumn{1}{|c|}{} & Beta & Std.Err. - of Beta & B & Std.Err. - of B & $t(40)$ & p-level \\
\hline Intercept & & & 15.29897 & 16.04831 & 0.9533 & 0.346160 \\
\hline$X_{10}$ & $\mathbf{3 . 7 8 9 5 9}$ & $\mathbf{0 . 3 2 6 3 2 9}$ & $\mathbf{1 . 1 0 9 7 1}$ & $\mathbf{0 . 0 9 5 5 6}$ & $\mathbf{1 1 . 6 1 2 8}$ & $\mathbf{0 . 0 0 0 0 0 0}$ \\
\hline$X_{11}$ & $\mathbf{- 1 . 9 0 1 3 1}$ & $\mathbf{0 . 0 8 9 6 1 2}$ & $\mathbf{- 0 . 9 5 8 3 0}$ & $\mathbf{0 . 0 4 5 1 7}$ & $\mathbf{- 2 1 . 2 1 7 1}$ & $\mathbf{0 . 0 0 0 0 0 0}$ \\
\hline$X_{3}$ & $\mathbf{- 0 . 9 3 5 9 3}$ & $\mathbf{0 . 3 5 8 0 8 4}$ & $\mathbf{- 0 . 0 8 0 5 1}$ & $\mathbf{0 . 0 3 0 8 0}$ & $\mathbf{- 2 . 6 1 3 7}$ & $\mathbf{0 . 0 1 2 5 6 2}$ \\
\hline$X_{6}$ & $\mathbf{0 . 0 2 8 4 4}$ & $\mathbf{0 . 0 1 3 8 3 9}$ & $\mathbf{0 . 0 0 8 8 6}$ & $\mathbf{0 . 0 0 4 3 1}$ & $\mathbf{2 . 0 5 5 1}$ & $\mathbf{0 . 0 4 6 4 3 5}$ \\
\hline
\end{tabular}

\section{Conclusion}

The aim of the paper is to provide better understanding of the social-economic, cultural and other changes of the population of Vojvodina at the end of $20^{\text {th }}$ century through the analysis of marital structure. The paper outlines the marital characteristics of the population of Vojvodina between the two successive Censuses (1991-2002). The marital status of the population of Vojvodina during the last 
V. Sokolovska, K. Čobanović, S. Nićin, Statistical Analysis of Marital Status...

decade of $20^{\text {th }}$ century is characterized by the model similar to the model of Western Europe countries in the last two decades of the last century.

It is evident that during the analyzed period some population categories increased: the single population, widowers/widows and divorced, while the category of the married population decreased. In the same period the divorced rate increased by the average annual growth rate of $0.125(\%)$.

A detailed analysis of the population of Vojvodina was made on the basis of the results of the last population Census (2002). The empirical results proved that there are significant differences between the families with or without children and with respect to the type of settlements (urban and rural). Using the model of multiple regression, it is evident that the number of families with children (urban and rural settlements) is significantly influenced by the total number of families and the number of families without children. Similar influences were identified for the families without children.

\section{REFERENCES:}

Bobić, M. (2006). Marital Status of the Population of Vojvodina at the Beginning of the Third Millennium. Zbornik Matice srpske za društvene nauke, No.121: 313-323.

Breaux, H. J., Campbell, L. W., Torrey, J. C. (1966). Stepwise multiple regression statistical theory and computer program description. Report No. 1330. Ballistic research labs Aberdeeb proving ground md.

Čobanović, K. Nikolić Đorić, E. (1995). Stepwise regresija i njena primena. Privredna izgradnja, Vol. XXXVIII, No. 1-2: 61-70.

Knjige popisa 1991 (1995). Beograd: Savezni zavod za statistiku.

Knjige popisa stanovništva, domaćinstava i stanova u 2002. (2005). Beograd: Republički zavod za statistiku Srbije.

Opštine u Srbiji 2006 (2007). Beograd: Republički zavod za statistiku.

Petrović, M. (2006). Bračnost sranovništva. U: Stanovništvo i domaćinstva Srbije prema popisu 2002. godine. Beograd: Republički zavod za statistiku Srbije, Institut društvenih nauka Centar za demografska istraživanja, Društvo demografa Srbije, str. 139-153.

Rašević, Mirjana (2006). Postponing of Childbearing in the Optimal Life Age - A Basic Demographic Consequence of the 1990s in Serbia. Zbornik Matice srpske za društvene nauke, No. 121: $141-148$.

STATISTICA 8.0 (2008). StatSoft, University Licence (University of Novi Sad, Serbia). 
Сочиолоики преглед, vol. XLIII (2009), nо. 3, стр. 329-341

Валентина Соколовска

Резиме

Филозофски факултет, Нови Сад

Катарина Чобановић

Слободан Нићин

Пољопривредни факултет, Нови Сад

\section{СТАТИСТИЧКА АНАЛИЗА БРАЧНОГ СТАҢА СТАНОВНИШТВА ВОЈВОДИНЕ}

У раду се анализа брачног стања становништва Војводине спроводи помоћу статистичких метода. Ова анализа је базирана на пописима становништва из 1991. и 2002. године. Период између два последња пописа (1991-2002) карактеришу веома динамични друштвени процеси у Србији (Централној Србији и Војводини), који имају и значајног утицаја на промене брачног стања становништва. Анализа је фокусирана на основне индикаторе брачне структуре: просечну старост становништва при склапању брака и коефицијента диворцијалитета код полне и старосних структура. Посебна пажња посвећена је истраживању сличности и разлика у брачности становништва Војводине према типу насеља: градско или сеоско.

Кључне речи: брачно стање, Војводина, статистичка анализа. 